\title{
Creativity and Control: Property in Guianese
} Amazonia

\section{Marc Brightman}

\section{OpenEdition}

\section{Journals}

Electronic version

URL: https://journals.openedition.org/jsa/11303

DOI: 10.4000/jsa.11303

ISSN: 1957-7842

\section{Publisher}

Société des américanistes

\section{Printed version}

Date of publication: 5 June 2010

Number of pages: 135-167

ISSN: 0037-9174

\section{Electronic reference}

Marc Brightman, "Creativity and Control: Property in Guianese Amazonia", Journal de la Société des américanistes [Online], 96-1 | 2010, Online since 10 December 2014, connection on 04 September 2022. URL: http://journals.openedition. org/jsa/11303 ; DOI: https://doi.org/10.4000/jsa. 11303 


\title{
CREATIVITY AND CONTROL: PROPERTY IN GUIANESE AMAZONIA
}

\author{
Marc BRIGHTMAN *
}

This article introduces the anthropology of property relations to indigenous Amazonia, where property has long been assumed to be absent, and shows that focusing on Amazonian forms of property can lead to greater understanding of native practices and institutions. The article begins by showing that the Trio, Wayana and Akuriyo of southern Suriname have a wide range of practices and values which can usefully be understood in terms of property. This provides the basis for a discussion of the analytical importance of the anthropology of property for Amazonia, followed by a consideration of the place of Amazonian forms of property in the context of anthropological theory. [Key words: Akuriyo, Amazonia, control, creativity, leadership, material culture, ownership, property, Suriname, Trio, Wayana.]

Créativité et contrôle: la propriété en Amazonie guyanaise. Cet article traite de l'anthropologie des relations de propriété en Amazonie indigène. Alors que, dans cette région, le concept de " propriété » a été longtemps considéré comme absent, nous démontrons ici qu'en s'interrogeant sur les formes amazoniennes de propriété, il est possible d'atteindre une meilleure compréhension des pratiques et des institutions indigènes. On s'attachera, tout d'abord, à montrer que les Trio, les Wayana et les Akuriyo du sud du Suriname possèdent une large palette de pratiques et de valeurs qui peuvent être comprises en termes de propriété. C'est sur cette base que l'on peut entamer une discussion sur l'importance analytique de l'anthropologie de la propriété pour l'Amazonie et repenser la place que les formes amazoniennes de propriété prennent dans le contexte des théories anthropologiques. [Mots-clés: Akuriyo, Amazonie, contrôle, créativité, leadership, culture matérielle, ownership, propriété, Suriname, Trio, Wayana.]

Creatividad y control: la propiedad en la Amazonía guayanesa. Este artículo trata de la antropología de las relaciones de propiedad en la Amazonía indígena, región donde la propiedad ha sido desde hace mucho tiempo presentada como ausente. Demostramos aquí que las formas de propiedad existentes en la Amazonía permiten una mayor comprensión de las prácticas e instituciones indígenas. Empezamos demostrando que

* ESRC Postdoctoral Fellow, Institute of Social and Cultural Anthropology, Oxford University, 51/3 Banbury Road, Oxford, OX2 6PE, Angleterre [marcbrightman@yahoo.co.uk].

Journal de la Société des Américanistes, 2010,96-1, pp. 135-167. O Société des Américanistes. 
los tirios, los wayanas y los akuriyos del sur de Surinam poseen una gran variedad de prácticas y valores que pueden ser considerados en términos de propiedad. Esta parte descriptiva permite que se discuta la importancia analítica de la antropología de la propiedad en el estudio de esta región y nos lleva a concebir el lugar de las formas amazónicas de propiedad en el contexto de la teoría antropológica. [Palabras claves: akuriyo, Amazonía, control, creatividad, liderazgo, cultura material, ownership, propiedad, Surinam, tirio, wayana.]

\section{INTRODUCTION}

The idea of property is one of the fundamental elements of much political and social theory (Ryan 1986) ${ }^{1}$. There has recently been a resurgence of anthropological interest in property (e.g. Hann 1998; Hirsch and Strathern 2004; Verdery and Humphrey 2004; Brown 1998, 2003; Kalinoe and Leach 2004; Moutu 2004; Posey 2004; Strathern 1999; Widlok and Tadesse 2006), to which Amazonianist anthropology has so far made virtually no significant contribution $^{2}$. This follows a tradition of Amazonian societies, even more than those of the rest of the Americas, being treated as though property were an institution alien to them ${ }^{3}$. Even within anthropology, there has as yet been no serious attempt to understand what kinds of Amerindian concepts might correspond to what is understood in other traditions as property. In this article I will argue that Amazonian societies not only have forms of property recognisable according to widely accepted basic criteria, but that they also present distinctive forms of property which are worthy of anthropological attention.

When the first systematic studies of Amazonian societies began to be made around the middle of the 20th century, some authors included brief sections on property. Fock dedicates nearly two pages to property in his monograph on the Waiwai: he notes that men, women and children have "personal rights of property "; that a father " owns » larger objects used by the whole family, such as a canoe, and that personal property may be bartered using an oho chanting ceremony; that fields, or specific portions of fields, are « owned » by individuals (Fock 1963, pp. 205-206). For the Cubeo of Northwest Amazonia, Goldman (1963, p. 71$)$ gives rather more detail, affirming that « [w]ith respect to land it is dominion rather than ownership that we deal with ", but that chagra gardens are a "well-defined item of property » and " the domain of a particular woman »; other types of cultivation belong to the cultivator while « the land on which they are grown has no standing as personal property » (ibid., p. 74; we shall see that there are parallels here with the Trio). Parts of the river are also staked out by men. Certain kinds of objects (those made for public use) are owned collectively by the community; other objects are owned individually. Goldman (ibid., p. 75) also makes the suggestive observation that " possessions confer human status. That is, a person should own things ». Many authors refer to property only as a 
synonym for moveable objects (e.g. Maybury-Lewis 1974; Rivière 1969); none interrogates the nature of property as understood by natives, and all appear to assume that property rights are unproblematic. A notable exception to this trend is Gregor, who notes the distinctiveness and complexity of possessives in Mehinaku grammar and underlines the relationship between property and personhood (« [ $\mathrm{t}]$ he Mehinaku interest in ownership is... built right into the structure of their language »), owned objects being more or less closely associated with individuals (a fact expressed in the possessive forms of nouns); he also makes thoughtful observations on the role of scarcity as a measure of value, taking this as a point of comparison with « our own society » (Gregor 1977, pp. 120-121). It is only very recently that this potentially rich line of inquiry has been revisited, notably by Costa (2010 in this issue, 2007), who shows the relationship between Kanamari personhood, leadership and ownership, and Fausto (2008a, 2008b), who argues for the all-embracing importance of relationships of " mastership " in native Amazonian social and cosmological relations. I became aware of the work of Fausto and Costa only after having developed the basic argument presented here, and the fact that we independently decided that it was time to argue for the importance of native property relations in Amazonia testifies to the strong foundations of the case.

It therefore seems all the more justifiable to place the evidence presented here in the context of the wider literature on the anthropology of property. However, I prefer to avoid a «top-down » approach to this subject such as that taken by Testart (2003), which imposes a European notion of property against which indigenous institutions are measured. As Neale (1998) has pointed out, Western ideas about property are " ideologically and historically specific », and empirical study is necessary to " discover and report rules of access before, not after; we invent universal concepts of property » (ibid., p. 57). Treating jural definitions of property from capitalist states as a gold standard (instead of a special case) risks giving rise to an ethnocentric analysis with limited anthropological value ${ }^{4}$. Instead, I will attempt to follow Rivière's (1993) call for an « amerindianisation » of key anthropological concepts, using a «bottom-up » approach (see Santos Granero 2009) to outline the distinctively Amazonian forms of property. To facilitate this approach, I will begin by presenting the forms of property found among the Trio and their neighbours of southern Suriname. I will then discuss property in the broader context of Amazonia. Finally, I will consider the Amazonian case against the wider anthropological literature on property.

\section{Possession among the Trio}

The Trio, and the neighbouring (and in certain cases intermarrying) Akuriyo and Wayana, are swidden horticulturalist hunter-gatherers of the terra firme 
uplands of the Guiana shield, most of whom have come from interfluvial areas to live in large villages that have grown up around missionary airstrips created on the banks of larger rivers in the last 50 years. Their transactions of objects and persons have come to involve cash purchase alongside sharing, barter and gift exchange, and transactions often lie mid-way between such categories.

There are three principal « types of possession » in the Trio language, defined, not by alienability/inalienability (a distinction of importance in many languages), but rather along "temporal parameters », which the linguist Carlin (2004, pp. 459-476) characterizes as: « immediate possession », « temporary controlled possession », and " permanent possession $"$.

The first type, for which Carlin gives the example of karakuri nai jiweinje, "I have money on me », as it deals with immediate possession, may not seem to be relevant to the notion of property, because if, for example, one does not have money on one's person, but in another place, then it is used in the negative. However, this impression may be due merely to a narrower definition of property than any we are used to. Yet even Adam Smith, while contributing to founding modern notions of property, conjectured that among hunters, because of their nomadic lifestyle, « the notion of property seems... to have been confined to what was about ones person » (Smith 1978, p. 485). Whether or not it is universal among nomadic hunting societies for immediate possession to be the primary notion of property, the suggestion does carry some resonance in the Guianas, and Akuriyo do tend to carry their most treasured possessions on their persons; it is worth noting that these are the items with which they would be least likely to part, and thus the immediacy of this form of possession has no relationship to the level of alienability of the objects concerned.

It is equally significant that the second form, temporary controlled possession, is characterised by control rather than alienability. Carlin's example is maja entume wae, "I have a knife [that I can give away] ». The word entu has no direct equivalent in English, but it carries the sense of both " owner » and " boss ». The Portuguese dono or Spanish dueño would be closer translations (see Fausto 2008b). It also means «trunk of tree» and "foot of mountain». The leader or founder of a village is known as the pata entu, literally the "place entu $"{ }^{6}$, and persons in charge of particular tasks, such as running the generator or the radio, are known as the montoru entu and the radio entu respectively. This is despite the fact that legally the radio in Tëpu, the village in which I carried out the majority of my field research, is the property of the telecommunications company, Telesur, and the generator that of the Ministry of Social Affairs. The common factor uniting these examples of entu is the practical element of being in charge of, being responsible for, and carrying out or delegating tasks related to the village, radio or generator. The suffix -me, here meaning " being in a state of ", gives entume. Entume wae means " I have it ", usually with a sense of control, and also implying an idea of mastery over a thing (see Fausto 2008a, 2008b): it can be 
used of objects that can be exchanged (bateri entume wae, " I have batteries [to give away] »; malaja entume manan?, " do you have a machete [for me]? »). Carlin does not comment on the fact that this expression may also be used to refer to features of one's own body: one man, for example, once used it to point out to me that he had a pierced septum, in contrast with another person who did not. Once again, this is because of the element of control - but also because of the transient nature of the body according to indigenous cosmology; although the man cannot « unpierce » his septum or give it away, and the piercing seems to be permanent, the humanity and integrity of the body must constantly be maintained by artificial means. It is also worth adding that the notion of ownership/control also carries an important sense of knowledge: to know something is synonymous with owning and controlling it.

A possessor in this type of construction must be animate, and $X$ entume wae means « I own/control X ». The question, karakuri entume manan?, " do you have money », implies a request for money, because it includes the suggestion « do you have enough money? », or " money to spare ", or " do you have control of the money [such that you can give me some]? ». Exchange, or giving, and control are united in this linguistic feature, and this is a crucial point to bear in mind to understand Trio notions of property. Although property relations of this type are transient, they are so in the sense that they imply the power to change: a village leader's position is subject to his maintaining certain relationships with his pëito (subordinates/sons-in-law) or villagers, who may desert him at any time; yet he has control of the village and represents it (in ways discussed below).

The emphasis on control highlights the political character of entu possession, and to understand this it is worth noting that, at least among kin, sharing is the predominant way in which things change hands; Guianese people obtain things from kin by demanding them, and greatly disapprove of « stinginess », just as in the "sharing » economies of many hunter-gatherers (Woodburn 1998). In view of this, however, we may wonder how people are able to maintain possession of the valuable industrially produced prestige goods that they often acquire nowadays. In fact they frequently do obtain such items by demanding them from wealthy outsiders (missionaries and NGO or government workers). Amerindian owners of such valuable and prestigious items are very unwilling to part with them, and this causes social tensions that would have been less acute in the past, when access to resources depended less upon client relationships with outsiders. However this change should also be seen in the context of the transition that has occurred between the small, largely endogamous and relatively short-lived settlements of the past (see Rivière 1984) and the large, permanent settlements that have grown up in recent decades around mission stations, in which affines live in close proximity and regularly interact.

Sharing is of central importance to leadership, and consequently personal influence often used to be inversely proportional to wealth, although this has 
changed now that leaders' positions are more secure due to the official state sanction of leaders as "captains », and to the presence of schools and clinics which reduce the likelihood of political factions departing. Even so, one of the two « captains » in Tëpu gives vast quantities of goods to his demanding fatherin-law and to other close relatives of his. He is constantly in financial debt, and has developed a reputation for bouncing cheques. Lévi-Strauss (1944, p. 24) called the leader's need to give in response to the demands of his followers the " first instrumental force » of the chief's power. I would add that the leader also has to accumulate more in order to sustain his giving, necessitating and facilitating his greater social connectedness.

Sharing relationships, meanwhile, tend to be expressed as "permanent " possession, of which Carlin's examples are: " "I have a father [tïpapake wae], a sister", or "I have a house [tïpakoroke wae]" » (Carlin 2004, p. 459). This type of construction describes a state, in these examples roughly corresponding to being " be-fathered ", " be-sistered ", or " housed ", and it does not imply any transaction. A permanent possessor does not have to be animate, and so features of objects or places can be described in this way. With regard to things as opposed to persons, whether they are described in terms of permanent or temporary possession depends upon context. In the case of "hammock", the noun itself changes from ëhke (permanent) to weitapi (temporary) to emphasize this distinction: tëhkeke manan? "do you have a hammock » (lit. "are you behammocked? »); weitapi entume manan? « do you have a [spare] hammock [that I can use/buy]? ». This is because hammocks can be made for trade or for personal use, and once they are appropriated in the latter case, they are permanent property and will not normally be parted with.

The animate or inanimate nature of the subject in possessive constructions is significant. Temporary controlled possession must have an animate subject. This supports the hypothesis that it is action or practice that makes property. Some kind of action - either through exchange or through the manipulation of materials in the forest or garden - must be taken in order to have a temporary controlled possessed object, and this requires an animate subject. In more general terms, whereas temporary possession is concerned with the thing possessed, permanent possession is concerned with a status or an identity, although both forms concern relations of one kind or another. Moreover, it is worth noting here that the "permanence " of permanent possession is only relative, and kinship relations also require constant upkeep through interactions of various kinds, especially eating and drinking together. A village leader more clearly owes his position not to an innate status, but to his foundation of a village and his actions (especially acquiring and giving objects) and speeches; it is these relationships and actions themselves that are described in terms of permanent possession; thus once again we find a certain continuity between ownership and political influence. 
While the distinction between " permanent » and other forms of possession lies in the extent to which person and object (or person and person, etc.) are bound up with each other, immediate possession distinguishes itself from the other forms by the concreteness of the property relationship. This corresponds to the Trio's emphasis in their language upon distinguishing the seen from the unseen, and the certain from the uncertain. One may be the owner of an item, but this is not the same as having it in one's grasp. Experience, relationship and intention are all thus mobilized even in the most everyday possessive constructions. This suggests it is inappropriate to discuss property in absolute terms.

I have introduced Trio possessive constructions in order to give a basic idea of how they refer to ownership and possession. However, the relationship between language and thought is problematic, and that between language and society is no less so: at best one must allow for the fact that if social practices and modes of thought find expression in linguistic constructions, these three things may not change at the same pace, and the relationship of causality between the three is difficult to establish. I therefore wish to avoid a more detailed discussion of the constructions presented above, as my objective here is to consider practices of ownership. It would be a mistake to offer the impression that possessive constructions can be taken simply and directly for categories of property. Instead, these constructions should provide a linguistic background to the concrete practices that I will now discuss.

\section{LAND: TRANSFORMATION OF THE ENVIRONMENT}

The most politically significant kind of property relations, in Amazonia as elsewhere, are perhaps those concerning the environment. Among the Trio, as I will show, it is clear that land used as gardens can be called property based on the criteria of usu, fructus and abusus (see Testart 2003). However, what constitutes these things is rather more complex, as is the set of relations that compose sovereign territory. Moreover, Trio modes of being and of interacting with the environment challenge the distinctions that these classical criteria are based on, and others implicit in Western distinctions between different kinds of property, especially between material and immaterial property, or between physical and intellectual property.

The Trio's relationship with the non-human environment resembles the « sentient ecology » of the Evenki (Anderson 1998) and their relationship with the landscape involves negotiations with non-human persons and immersion in histories of "wayfaring » (Ingold 2000; see Merleau-Ponty 1945; Lévi-Strauss 1962; Descola 1986). In Trio, location is expressed by suffix in one of five ways, distinguishing open space (pata-po, in the village), enclosed space (itu-tao, in the forest), in liquid (tuma-hkao, in the water/ river), in fire (mahto-renao), or in 
contact (itu-pë, on the branch) (Carlin 2004, p. 172). The qualitative difference between types of space is most important between the village and the forest, space being subjectively experienced, either from within the forest or " at » a place or village. Rivière has rightly drawn attention to the strong cosmological distinction between itu and pata, the latter meaning « village » or " place », and itu meaning " forest » or " without a place ». However, rather than seeing the village as simply surrounded by forest, there is a further sense in which " place » includes human paths through the forest: if " place » corresponds to a network of histories, then itu is the holes in the net. Rather than call it "without a place ", it is useful to think of the forest as "non-place », to highlight its character of alterity and non-identity. Its alterity is not so much a characteristic of the forest itself as of its non-human inhabitants: plants, animals and spirits. Human relationships with these are part of a " sentient ecology » (Anderson 1998) which can be understood in terms of property relations in ways discussed below.

The artificial, the made, and the social are, on the other hand, clearly " owned » in some way or other almost by definition ${ }^{7}$. Cultivated land becomes " somebody's » garden; a basket becomes the property of its maker or a person to whom he gives it, until it begins to rot or fall apart, and it is left to the wiripëhtao (T), the liminal fringe of the village where rubbish is thrown to return to the forest. This distinction between inside and outside has political dimensions which Menget (1993, p. 60) has suggested constitute the very definition of a polity. Place-making, like human relationships, depends on the domestication of space; ownership of land is the same as cultivation of land, which is the expression of the historical relationship of a person or group to a place. But Amerindian polities and places are not quite so clearly identifiable; nor do they correspond precisely to each other.

Itu represents a category that cannot be owned as such. But there is a sense in which areas of forest belong under the political sovereignty of a village. This appears clearly in the history of Trio relationships with gold prospectors. For a period during the 1990s, the captain of Tëpu tolerated the presence of Brazilian goldminers in the forest within the sphere of influence of the village, in return for payment in gold. After becoming worried about the undesirable consequences of their presence, such as alcohol and drug abuse, and mercury pollution, he changed his mind and told them that they were no longer welcome; they duly left and have not returned since. There are cases in which the sovereignty of a local leader is not respected in this way, such as on the Lawa and Litani on the southern reaches of the border between French Guiana and Suriname. Here, gold prospecting is more intense and the situation more complex. Some Wayana leaders contest the presence of gold prospectors, whereas others collaborate with them in return for remuneration. Meanwhile, the involvement of Maroons makes gold prospecting an additional factor in a long history of territorial rivalry between Maroons and Wayana. 
In both situations, one principal remains constant: when gold prospectors are allowed to work within the sphere of political influence of a Trio or Wayana village, they are conceded usufruct, but must pay a form of rent or compensation (refusal to do so is seen by the local leader as an affront). The land that they use does not ipso facto become their property, and the local leader can, in principal, demand that they leave. This is clearly quite different from the case of ordinary Amerindian land use for cultivation, in which a garden is the property of its creator. Does the possibility of conceding land temporarily to the Other, to non-Trio and non-Amerindians, constitute a new form of property relation? While this might be so, it seems likely that it does not affect the logic of Trio property relations, but rather the changes in relations with alterity that have occurred through pacification, sedentarisation and evangelisation. In the past, enemy groups who tried to appropriate land for gardens and settlements on land considered by a given group of Trio to be their territory would not simply have been given property rights to the places concerned by virtue of their transformation of the environment. They would either have been attacked and killed or expelled, or friendly relations would have been established, eventually to convert them into kin; however neighbouring groups would be unlikely to try to establish gardens or villages on each other's territory without first establishing friendly relations and (as this usually implies) intermarrying ${ }^{8}$. In view of all this, we can affirm that for the Trio sovereign territory can be distinguished from place and property. Territory and place can be thought of as potential and actual property respectively.

In some respects the above argument echoes the labour theory of property, the enclosure of the commons in European history, and of the legal justification for colonialism that only cultivated land constituted owned land, making clearing, ploughing and sowing tantamount to a legitimate claim (see Locke 1988; Rousseau 1992; Smith 1978). This underlines the common element to all forms of property - that is, narrative, or history. It is events, and the history of a relationship, that make people belong to each other, and things or land belong to people; and the narratives of those events can turn them into property. To take possession of something can create ownership. In French Guiana, as in many Amazonian states, the state still allows individuals to « stake» a claim to a piece of land by enclosing, clearing and cultivating it ${ }^{9}$. The Western practice of «staking " claims may seem to suggest a difference between this cornerstone of colonial appropriation and the apparent idiosyncrasies of indigenous Amazonian culture: ambiguity and change or impermanence, leading to the need for constant renewal of ownership, are vital parts of Amerindian property relations, whereas Western property relations appear to strive to eliminate ambiguity and achieve permanence. But in fact the difference is not so clear. Native Amazonian property relations also involve constantly striving to perpetuate ownership in the face of the constant threat of transformation of 
status and relation, and Western property relations also emphasise that use is a necessary condition for the continuation of ownership: for instance in French Guiana "staked » claims are " renewable » every five years as long as they continue to be cultivated ${ }^{10}$.

Sovereign territory in the Guianas, from an indigenous perspective, is defined by the activities of the people who hunt, fish and cultivate there. But if creativity begets property, this does not necessarily mean that people produce territory, rather than the other way around. The situation is more ambiguous: for example, there is some indication in this region of the existence of ancestral places and of territorial emergence sites. The mountain called tukusipan can be regarded as an archetype of the Wayana house, and paiman, the Trio word for a large communal house, is also the name of a mountain. Moreover the Trio associate their ancestry with the savannah area called Samuwaka, south of Tëpu on the Brazilian side of the watershed. However this has little impact on the practicalities of residence or cultivation ${ }^{11}$. Rather than either land or people being prior to the other, there is a complementary and mutually constituting relationship between the two, in the sense that Ingold (2000) argues is also typical of circumpolar societies.

In practical terms, with regard to contemporary land claims, in the Guianas, it is only with the emerging possibility (and necessity) of formal, state-legislated land claims that the notion of entitlement has become relevant ${ }^{12}$. Notions of ancestry, descent and lineage, which ordinarily play little role in indigenous Guianese kinship ${ }^{13}$ and almost none in the relationship towards the land, become mobilized as part of strategies to retain land under pressure ${ }^{14}$. There is a key general point to be taken from this: property rights, as exclusive ownership, are only necessary where there is competition; or, as Hume (1975) argued, such property rights only make sense when they are in the interests of society. I suggest that the notion of creativity, which Strathern employs to show how land ownership can be similar to intellectual property, is even more important in the Guianas, because not even the group's relationship towards the land can be taken for granted. Only social relationships are emphasised, and gardens themselves, which can belong to individuals, must be created from the forest by transforming the places of non-human persons ${ }^{15}$.

The forest is associated with the spiritual realm, and belongs to shamans in the sense that it is their sphere of influence, and it is " proper » to them: ordinary people claim ignorance of it, whereas shamans « have » spirit familiars which are exclusive to them and, as with other forms of property, these must be actively maintained (by feeding with tobacco smoke); this of course is a fragile and impermanent form of property, being located in a shifting and uncertain dimension. The spatial organisation of spirits is also a form of belonging, and it is expressed in the narrative articulation of the forest. This spatial dimension of the spirit world has important implications for perspectivist theory, which tends to 
focus on abstract relations without taking into account the effects of time on the spatial organisation of humanity and alterity. Spirits belong to particular places (or the places belong to them), whether because they are the homes of the masters of animals, or because they are old villages, as a result of the histories of those places. Evangelical missionaries regarded this as a central problem when they were attempting to convince the Trio and Wayana of the superiority of their religion, and mounted expeditions to go to the " great jaguar's village » or the " great deer's village » to « demonstrate » that there was no danger in going there. A place of historical and spiritual importance is one in which an important transformation has taken place, or in which a highly transformable being dwells, and part of the danger of such places is that further transformations, beyond the control of Trio and Wayana people, may take place there in the future. The " masters » of animal species, such as the " great » jaguar and deer mentioned above, are those which can transform themselves into proto-humans, and which control the provision of game animals. Trio also avoid old villages because of the presence of dead people's spirits, who, lacking bodies, and therefore lacking human perspectives, will try to usurp the bodies of those who come near. In the case of these spirit places, which are given names although they exist in the forest, naming marks them as non-human property, and excludes them from the artificial processes (clearing and building or planting) that would appropriate them as human property.

Thus, even if the forest is "non-place », this does not make it terra nullius; it is not empty « space », but is instead the place of alterity. The transformation that occurs when creating a village or garden is the transformation of alterity into kinship: clearing and burning, it is hoped, send the spirits away, and they are replaced by manioc clones in the garden, which, as persons nurtured as though they were kin, are truly domestic plants; this echoes the "planting » of kin in the village, and likewise leadership and collective labour permit this creative appropriation of social space.

\section{LEADERSHIP AND VILLAGE FOUNDATION}

Villages are named after, and "belong " to their founders or " owners " (entu) ${ }^{16}$. In more general terms, it may be said that places belong to, or are owned by, their makers; to create is to own and control. Village foundation is thus of great importance as a political activity (see Menget 1993, p. 69; Heckenberger 2005 passim). A Trio man wishing to assert his independence and his leadership qualities founds a village or, as often happens in today's large villages centred on health and education providers, he founds a new section of a village. This involves the organization of labour to clear and build, which creates a proprietorial relationship of authority (where one does not already exist) between a founder 
and his followers; a leader can say "pëito entume wae ", "I have (temporary controlled) a follower ». In most cases, village foundation involves the division of a previously existing local group, and therefore constitutes the creation of a new polity. For these reasons, it can be regarded as the political act par excellence: the group comes together (in a particular place) around a leader (who chooses that place) ${ }^{17}$. Villages, like houses, are usually named after their builder/founders: they are biographical entities.

If villages are named after persons, this does not merely associate them with an individual. The resonance of a name should be understood in light of the fact that, among the Trio and Wayana (as among the Iatmul of Papua New Guinea), "names contain relationships which people own » (Moutu 2004, p. 108). However, names do not have the same exclusive value for the Trio and Wayana as for the Iatmul, and disputes over property are rare; such conflicts are preferably avoided. Almost every individual has a unique name, and new names are enthusiastically adopted from outsiders. Although I was unable to obtain a clear explanation of this, it is coherent with the tendency to bring in persons and things from " outside » to renew and nourish the " inside ». At the same time, each name reflects its source, and names are often adopted with the permission of their original holder: parents of a newborn child sometimes ask a nonAmerindian outsider if they can name the baby after them. The name thereafter contains the relationship ${ }^{18}$. Naming a village thus leads to the encapsulation of the network of relationships comprising the future residents of the village in the name of its founder.

Villages in the past (i.e. until the mid-20th century, when the most intense period of evangelisation in this region began) were smaller than they are now ${ }^{19}$, and many contemporary villages were not founded by Amerindians; largely because of the attractions they present such as a school, health post and airstrip, they have lasted more than a generation and grown to unprecedented proportions. Yet sections of the village (which in some cases are spatially quite distinct and separate) are themselves referred to as pata. They are named, as all villages were in the past ${ }^{20}$, after people rather than features of the landscape. There is a segmentary logic to village naming: when in the city, jipata refers to " my » village as a whole, but when in the village, jipata refers to "my " section of the village. The pattern of abandonment and foundation of sections nevertheless follows that of villages in the past ${ }^{21}$.

Settlement solidarity revolves around the founder of a village or village section, and is based upon his authority over his daughters and sons-inlaw. The practice of destroying the possessions and often the house of the deceased used to extend to the entire settlement in the event of the death of its leader. This was the occasion for the migration of all the remaining residents - and often their simultaneous dispersal as rival new leaders founded separate new settlements. Today, numerous sites on riverbanks are spoken of as 
abandoned settlements where a pata entu died. Such places are said to be infested with spirits, and unsuitable for settlement or cultivation. They can be known as "X's old place» or using toponyms. Within today's larger, more permanent village, houses and even whole sections may be abandoned at times for the same reasons, but relocation may take place within the larger village. Here the problems with household location tend to be associated with the proximity of affines, rather than with the presence of spirits; although both are analogous to each other as they are both examples of the dangers attributed to alterity.

Evangelical missionaries named new villages after features of the landscape as part of a strategy to create permanent settlements. By giving neutral names, " rock » (Tëpu) or Lawa (the name of a river), and installing a church, a medical centre, an airstrip and a school, they created a permanent centre of attraction, a nexus of spiritual and material resources, around which smaller, kin-based villages (founded in more or less the usual way) cluster. The village of Tëpu is often referred to as a " white people's village » [Pananakiri ipata $(\mathrm{T})$ ], because it was founded by American and Dutch missionaries ${ }^{22}$. « White peoples' villages » tend to grow bigger and last longer than traditionally founded ones. This is because of the desirable external resources that the white people themselves bring, including metal goods at first, and later schools and clinics, but it is also likely to be because of the diminished need for relocation, because the white founders are less likely to die in the village.

There is a clear relationship between village permanence and its foundation by a « White » outsider. Most « permanent » villages appear to have been founded by outsiders: Tëpu, Kwamalasamutu, Palumeu, and Apalaí. Apart from the fact that outsiders often create attractions that outlast their own presence (clinics, etc.) because they represent larger organizations, I suggest that it is also significant that missionaries and other outsiders rarely die in the field, and when they do their remains are quickly removed. The form of village leadership or ownership that they represent is different from that of the Indians themselves in many respects, but the spiritual danger that their death would bring to a village never seems to have posed a problem. A large part of the danger of the spirits of the dead stems from their desire to rejoin the social world of their former kin; non-Amerindians, however long they remain in a village, do not usually become socialised in the same way, and rarely marry local people. Missionaries in particular deliberately maintain a certain aloof distance. The Trio are therefore in no danger living in Tëpu, for example, as the main founder returned to the USA long ago. Although he is still alive, when news of his death reaches Tëpu, as one day it will, it is highly unlikely that people will take any action as a result. This curious situation of an absent village founder has allowed a village to exist indefinitely without disturbing traditional property relations. 


\section{OWNERSHIP OF PERSONS AND THINGS}

The leader's role as " owner» of the village also corresponds to a form of « ownership » or " mastery » over the villagers, his pëito or subordinates. The relationship between leader and followers is modelled upon that between father-in-law and son-in-law, and is the basic relationship of inequality among the Trio (Brightman 2007; see Karadimas 2000). It takes its strongest form in the " ownership " of Akuriyo, the remnants of a hunter-gatherer people captured during evangelical raids in the late 1960s. The Akuriyo were parcelled out among the families of those involved in the expeditions, and today they remain attached to these families. They do not have their own cookhouses, and they are sent to hunt, fetch and carry by their Trio « owners ». Trio refer to « owning " Akuriyo (entume wae). This relationship seems close to that of the Waiwai and the " unseen peoples » whom they captured and incorporated in a context of evangelical missionary activity (Howard 2001); but the difference is that the Akuriyo have not been incorporated by the Trio and have instead remained as subordinates - in Tëpu, the village in which I carried out most of my fieldwork, there were no cases of intermarriage. The case thus also recalls the Amerindian slavery practices of the more distant past (Santos Granero 2009) and among other contemporary peoples such as the Yuqui (David Jabin personal communication 2008). I do not have space here to engage in a detailed comparison of the Akuriyo and the appropriation of other, non-human persons; however, it is useful to see the case as the strongest possible evidence of the appropriation of persons in a supposedly egalitarian Amazonian society (pace Overing and Passes 2000), and it seems reasonable to call this ownership of persons a form of « slavery ».

Animals and plants, which are also generally considered as types of « person », are appropriated in similar ways, and plants, « bushmeat » and live animals are traded routinely; as I have discussed elsewhere (Brightman 2008a), of these three forms of trade, it is those of plants and bushmeat that seem to raise the most anxiety about possible repercussions. These repercussions would in theory come from the spirit "owners" or masters of the animals or plants concerned. For example, when two women died from cancer in the early 1990s, their husbands stopped hunting for the bushmeat trade, because they attributed the illnesses to the anger caused by their immoderate hunting. In the case of artefacts, it is those who make the artefacts that own them; once again, creativity begets ownership. However, objects, like meat and food plants, enter into a cycle of transformation and reciprocity; manioc presses, for example, are made by men for their wives, who use them to process manioc planted by men and collected by women, and so on. Objects and food are clearly not held in common, and there is an important distinction between the demand sharing that is usually practiced and common property (or absence of property). People do not simply help 
themselves to the food or objects of other households; they ask for whatever it is that they want, and the absence of a monetary value or legal right does not detract from a person's prerogative to dispose of their property.

The disapproval of meanness is characteristic of the Trio's attitude towards persons and things as property. Possession and property amount in practice almost to the same thing, however, and little distinction is made between giving and borrowing. Having said this, the use of money and the increasing presence of long-lasting manufactured items are giving rise to an increasing tendency for people to lock their houses and secretly hoard objects. This is in contrast to the ostentatious way in which certain prestige items are displayed, such as relatively expensive clothes, watches and other paraphernalia. These appear not to be transferable, and may be regarded as « permanent » extensions of the person who wears or carries them ${ }^{23}$.

Some objects are clearly gendered, as everywhere in Amazonia: most obviously, hunting paraphernalia and fishing tackle belong to men and cooking utensils to women. More interestingly, men vigorously maintain their monopoly on any items which involve interactions between non-kin. A good illustration of this is the case of the motorised manioc grater that was brought to Tëpu and first put into use while I was there. Manioc grating is women's work, but men maintained control of the machine (this was made easier for them by their ownership of the fuel). Whenever a group of women wanted to use the machine, they would ask permission of its male " owner ", and he would set the machine in motion. The women, some of whom paid a small fee (depending on their relationship with the machine's owner) could then unload their katari of manioc into the machine.

The overriding factors in the appreciation and value of ordinary material objects tend to be age and usefulness. Old things are generally regarded as useless, and novelty, beauty and desirability are expressed together in the word kurano. The vast majority of everyday objects are utilitarian: cooking utensils, manioc squeezers, hunting and fishing equipment - and it makes sense that the newer they are, the better condition they are in, and therefore the more valuable. The same pattern partly applies to ritual and ornamental objects, whose value may also in a sense be regarded as utilitarian in terms of their functions such as protection against spirit attacks, or invigoration of the body. The exceptions to this are bead necklaces, feather headdresses, panti waist adornments, keweiju bead aprons, and flutes (or parts of flutes) made of bone or claw. These, although considered more beautiful when they are new, have greater value precisely because of their durability or " hardness » (T. karime). Glass beads are preferred to seeds not just because they are more difficult to procure, or because they require less work (seeds must be toasted, pierced and dyed), but primarily because of their far greater durability. The history of the beads themselves is given no importance, and good quality glass beads can be recycled when a particular 
ornament begins to become unstrung; women are forever requesting the particular colours they need for the design they have in mind. More elaborate feather ornaments are kept, for as long as possible ${ }^{24}$ and, along with other highly valued items, may be inherited; shamans in particular passed their rattles (and, more importantly, their contents) down to their apprentices (Peter Rivière personal communication 2007) ${ }^{25}$. However, many ritual objects are also quite disposable. The clarinets associated with the Wayana marake initiation ceremony are made especially for the occasion and are discarded afterwards, not because of pollution, but because they have fulfilled their purpose and will no longer be new or beautiful (kurano) by the next ceremony.

Today, the value of ceremonial artefacts, particularly the maluwana, a disc of silk cotton wood (Ceiba pentandra) painted with images of animals and powerful spirits traditionally displayed in Wayana roundhouses, is sometimes measured by their cash value when they are made for sale to tourists in the city ${ }^{26}$. This suggests that the property value of an object is not intrinsic to the type of object, but to the purpose for which it is made. A maluwana is the permanent property of a collectivity, when it is designed for its usual purpose, as a ritual ornament for the communal meeting house (tukusipan). When it is made for trade, on the other hand, it is referred to as the temporary controlled property of the maker. This illustrates how economic strategies can define the form of property relations that exist with a given object. In exchange, Trio property relations do not radically distinguish between White "commodities » and Amerindian " gifts " or make any such simple dichotomy. Rather, they treat property more inclusively the more closely related they are to the persons involved, and more exclusively the less closely related they are (see Carrier 1998). This is not the same thing as a gift/commodity distinction, because it works on a continuum ranging from sharing to commodity exchange. It is effective levels of sociability that count rather than " ethnically » determined categories.

\section{Property in Lowland South America}

Testart (2003) argues that theories of primitive communism led earlier Africanist ethnographers to posit the existence of communal, ancestral property in land, divine and inalienable, which was parcelled out in usufruct. He shows that this theory was based on inconsistent definitions of property and poor interpretation of ethnographic evidence. If the myth of primitive communism lingered in Africanist anthropology long after it was discredited elsewhere, a similar myth persists in Amazonianist anthropology. Rousseau began a tradition of assuming Amerindian societies to be still more primitive survivals from before the emergence of property. This tendency has been left unaddressed since the fall from grace of evolutionary paradigms in social anthropology, perhaps because it has 
been overshadowed by structuralist interest in myth and kinship terminology, and by the opposition of Amazonian societies to Western societies. The former have been portrayed as ideologically egalitarian, shumning property and the inequalities it creates (Clastres 1974; Overing and Passes 2000), or as inverting Western dichotomies such as that between culture and nature (Viveiros de Castro 1998). I do not wish to diminish the achievements of this tradition, but rather to expose the fact that it has left a vast area of study in Amazonian ethnography unaddressed, and, more seriously, has perpetuated an idealised image of indigenous Amazonians as somewhat ephemeral or ascetic beings, unburdened by material desires. Even the proponents of "political economy » style of analysis ${ }^{27}$, such as Rivière (1984) and Turner (1979), failed to develop a theory of property specific to the region; instead, they imported more or less explicitly Marxist-influenced ideas of property, while subverting them by emphasising the value that native Amazonians give to people rather than objects. By doing so, they made important theoretical points, but they drew discussion once again away from material culture. Even in more " engaged " branches of Amazonian anthropology, as in political activism, which focus on problems over resources, discourses about land and intellectual property rights take Western forms of property for granted rather than considering how these might appear from an Amerindian perspective, presenting property as a Western and colonial " problem » imposed on indigenous peoples, contrary to their « rights » according to international law (e.g. Brown 1998; Kambel and MacKay 1999; Posey and Dutfield 1996). Meanwhile, the definition in principle of these rights themselves, recently formulated as «indigenous » rights, is not based upon rigorous ethnographic data ${ }^{28}$.

Hugh-Jones (2009) has recently challenged the anthropological tradition of minimising the significance of objects in Amazonia. As he has argued, there is a long-standing tendency in Amazonianist anthropology to focus on people rather than things, the invisible rather than the material, and to suppose that persons and things come into being through processes of transformation rather than creation. By presenting the case of Tukanoan ancestor cults, he shows that Amazonian societies do carry a structural potential for objects to play a key central role, and for creation ex nihilo. Although he does not discuss the question of property, its importance is implied in his argument, for the ownership and transmission of crafted « heirlooms » by patrilineal groups is at the core of the case he presents.

Certain received ideas about property are often implicit in Amazonianist ethnography. Heckenberger $(2005$, p. 18) has noted the "entrenched view » in Amazonian anthropology that Amazonian groups practice "balanced exchange » or " reciprocity » in a " "gift economy" (i.e. lacking "property" or other "commodities") ». Indeed, by equating « property » with " commodities » Heckenberger reveals that his own approach to Amazonian property is far from 
systematic. There is plenty of evidence of indigenous forms of property in Amazonia apart from those I have discussed; take, for example, the ownership of names or narratives in central Amazonia (Lea 1995; Heckenberger 2005) ${ }^{29}$, or of flutes or feather ornaments in Northwest Amazonia (Hugh-Jones 1979) ${ }^{30}$. Heckenberger (2005) himself recognises the significance of names and types of speech as property in Xinguano society ${ }^{31}$. He calls the act of inscribing social memory on the landscape " place-making » (ibid., pp. $242 \mathrm{ff}$.), and because of Xinguano emphasis on ancestry, ancient plazas « constitute a kind of founder's property..., the first-in-lines of ancestral estate » (ibid., p. 290). As I have shown, although Guianese people do not emphasise ancestry, the relationship between foundation and property is the same, and village foundation gives leadership a privileged place in the constitution of property relations.

Another Xinguano feature shared by the Guianas is the exclusivity of certain property relations: in deciding to create or foster certain relationships, a person often breaks or neglects others, and the creation of new villages and new leaders through place-making is often the direct result of a split in another village (see Rivière 1984). This separation and definition of new entities is greatly significant, and the same processes take place on a smaller scale, within the kin-based village itself.

According to McCallum, for the Cashinahua properly owned items are " aspects of the person who owns them... ». Therefore « food and things may be owned absolutely ", and everything else, including land, may only have " connotations of ownership ». She adds, rather ambiguously, that this " attitude spills over into » parent-child relations, while asserting that interpersonal relations are nevertheless « in no way comparable to relations between persons and things » (McCallum 2001, p. 92). Such a categorical assertion could not be made about the Trio and Wayana (and McCallum's ambiguity makes it unconvincing for the Cashinahua). Types of property relations are more nuanced than a simple distinction between the alienable and the inalienable. Food is an obvious example: game animals are emphatically not « owned » by the hunter, who shuns any spoken reference to his involvement in their death; once brought home, they enter a cycle of transactions, starting with the women who butcher and cook, and culminating in dispersal through demand-sharing. According to McCallum's own scheme, it would also be difficult to account for exchanges of objects or persons without accepting that persons can in some sense also be property, because she asserts that « the thing "is" the person » (ibid., p. 93). The difficulty with McCallum's argument is that she does not distinguish between human and non-human persons: for instance, even if Trio and Wayana human persons are not directly exchangeable for objects ${ }^{32}$, they nevertheless constitute one form of property, and objects (including plants, which may be persons) constitute another; the difference is that the exchange of human persons causes a proliferation of inclusive ties of property and belonging, because it creates kinship ${ }^{33}$. 
Moreover, as we have seen in the case of Akuriyo slavery, human persons can be owned even if this does not necessarily mean they are traded.

Social formations in the Guianas have been described as lacking in the complexity, in both the material and the immaterial worlds, found in other regions of Amazonia: villages are impermanent and people do not derive their identity from a common ancestor; wealth tends not to be accumulated ${ }^{34}$. Overing (1986, p. 151) claimed that the Piaroa's renunciation of property was at the foundation of their egalitarianism: "In the Piaroa view, they have eradicated coercion as a social or political force within their society by refusing the possibility of the human ownership of material resources ». These features of "lack » would appear to suggest that property is unlikely to be an important notion in the region, but in fact what they represent is the long-standing tendency in Amazonian ethnography to swing between Rousseauesque idyll and savage Hobbesian anarchy ${ }^{35}$. I suggest that these complementary poles of caricature are based in large part on the lack of recognition of indigenous forms of property ${ }^{36}$. This tendency comes partly from observers' insufficient questioning of their own assumptions; in the case of property, they did not find in Amazonia something corresponding to the codified private property of their own society ${ }^{37}$. The ideological distortion of Overing's statement quoted above seems to be confirmed by comparison with her own evidence in her monograph (Overing 1975), the index of which has no fewer than 12 entries under " ownership » referring to pages describing features very similar to those of Trio ownership presented here; by her own account the Piaroa do not « lack » property at all.

Writing about the Trio, Rivière (1969) makes a distinction between " poorly » and «well » developed concepts of property. The former are moveable objects made from forest resources, which are readily available to any conjugal unit. The « well developed » form, which he notes has important political implications, is that of women (ibid., p. 41). He places in between these forms certain items " such as dogs, exotic manufactured goods, and certain cultivated plants » (ibid., p. 42), that is, " property, other than women, which has an intrinsic value, and cannot be replaced by any member of the society out of the resources of the environment ». The economic and political importance of these items has greatly increased with expanding trade since Rivière's fieldwork, but the principle remains valid, at least insofar as it is more appropriate to distinguish between resources that rely upon relations with other human persons, frequently affines (being obtainable only through exchange) and those that rely upon personal skill (which an individual can obtain independently), than to distinguish between " codified » property and « uncodified » possession.

As all this suggests, property has been given piecemeal attention in Amazonian ethnography, but it has rarely been placed at the centre of analysis. A rare exception, Vienne and Allard's (2005) account of regimes of ownership of intellectual property among the Trumai, focuses on the " potential for conflict » 
as a defining aspect of Trumai strategies of exchange, and argues that because shamanic and ritual songs can be passed on without such potential, these intellectual goods constitute " another order" of property from material possessions, the former being a type of « bodily transformation ». Unfortunately, the authors do not tell us more about the « material » order of property. Instead, they make a distinction between " objectifying " Western forms of property and an indigenous form of " possession » concerned with bodily processes and social relations. This recalls the distinction between gifts and commodities questioned by Carrier and Heckenberger (see above and below). It also resurrects Rousseau's distinction between primitive " possession " and civilized, codified " property " which, though inspired by accounts of Carib Indians, was intended as a commentary on modern society rather than as a serious attempt to describe Amazonian or " primitive » man (Ryan 1986). Besides these problems, it strikes me as unlikely that material and « cultural » forms of property can be so neatly distinguished.

An interesting line of inquiry on the subject of Amazonian property has been opened up by Freire who, writing about Piaroa understandings of land rights and territoriality, shows that « for the Piaroa the notion of private property is more concerned with transformation and continuity in the natural environment than with the land or natural resources themselves » (Freire 2002, p. 218). This recalls what I have argued above, that it is actions and relationships that are important in Amerindian regimes of ownership and exchange. But it is also important to give more attention to the structures of ownership, which I have tried to give a sense of here, and my understanding of it is in tune with that of Fausto (2008a; 2008b), who has begun to look comparatively at the importance of « mastery » in various forms across Amazonia (ownership, leadership, spirit familiars...) and argues convincingly that this demonstrates the way in which inequality, or disequilibrium, lies at the heart of Amazonian sociality, an argument which resonates with my own analysis of indigenous leadership (Brightman 2007).

\section{Property AND PROPERTY RELATIONS}

Recent work on the anthropology of property has found consensus in its focus on property relations as forms of social relations (Hann 1998, p. 4), specifically as relations between persons with regard to things (Verdery and Humphrey 2004), with property itself loosely defined. It has flourished in comparative expositions (Hann 1998; Hirsch and Strathern 2004; Verdery and Humphrey 2004; Kalinoe and Leach 2004; Widlok and Tadesse 2006), characterised by attempts to understand traditional or indigenous forms of property and cases of contact, influence or conflict with European forms in light of one another. Few authors have tried to establish a basic, cross-cultural definition of property; instead, most tend to emphasise the diversity of forms of property. An exception is Testart (2003), who, 
in the first of his essays on land as property in Africa, uses the classic jural definition of property as having three basic characteristics: usus, fructus and abusus; thus, to be seen as proprietor of an object, one must be able to use it, to enjoy its fruits (when applicable, as with cultivated land), and to destroy or dispose of it. On this basis, Testart distinguishes political sovereignty from property (as the former does not include use), and shows that the system of land as property commonly found across Africa is based on village sovereignty over a territory and the right of each " citizen » or member of the community to have land to cultivate. Uncultivated land is nobody's property, although it falls under the political influence of the village. The sovereign, or local leader, "shows » a piece of land to those who ask for it (new members of the community or those who have new mouths to feed), and the latter then appropriate the land through cultivation. By using the land, it becomes their property; they have the right to the products of their cultivation, and they can also, if necessary, dispose of the land by selling it. As I have shown, the Trio's relationship with the forest environment has much in common with this scenario, and the distinction between cultivated (or transformed) land as property and a more loosely defined sovereign territory is significant. But this sort of characterisation is severely limited by the top-down imposition of European jural criteria, and does little justice to the complexity and richness of the Trio practices of appropriation that I have described.

A more promising theoretical approach is taken by Strathern (s. d.) who, writing about anthropological notions of space, landscape, territory and property, uses Melanesian examples to argue that land can usefully be understood as both a tangible and an intangible resource. Following Corsín-Jiménez (2003), she suggests regarding land in various ways in terms of space rather than landscape. People in Melanesia can be said to "belong " to the land, as much if not more than it belongs to them, and the creations of the land can be seen as creations in ways similar to the intangible resources of intellectual property. The nexus of relationships between people, land and produce " gives us the rules of exclusion " (Strathern s. d., p. 12). What people value in the land is not so much its capacity for production, as its capacity for relationships. In this respect, the Trio case is similar; relationships and the capacity for relationships are certainly important criteria for valuing land; although it is somewhat difficult to separate these relationships from the notion of productivity that they in fact imply: the Trio value their relationships not only with each other, but also their ambiguous relationships with non-human persons, including the animals and plants, or the spirit-owner-masters of those animals and plants which they consume as food.

More problematically, at least for comparative purposes, Strathern (s. d.) and Corsín-Jiménez (2003) also claim that it may be inappropriate to employ the concept of landscape to space. I would suggest, following Ingold (2000), that this distinction makes little sense, since few peoples impose abstract cultural meanings on a neutral "space», but instead draw it from interactions with their 
environment. The Akuriyo, Trio and Wayana reinforce places and their meanings through shared experience, and they express belonging through situated narratives. Itu may thus be represented and experienced, often through interpersonal relationships with forest-dwellers (animals and spirits), whereas pata and tëpitë (the garden) are transformed as well. This presents some important differences with Strathern's Melanesian scenario. In the Guianas, because of the clearly differentiated spatial categories that define the relationship with the environment, the general concept of « land » is almost meaningless, and still less is there such a thing as an abstract and value-free notion of "space». Space is basically either village or forest. The distinction is between cultivated and Other (rather than natural), since the forest «belongs » to non-human persons who « cultivate » it in their own way ${ }^{38}$; it thus corresponds to the distinction between consanguinity and affinity. In Melanesia, fields belong to lineages and are associated with particular ancestors ${ }^{39}$. They can be left fallow, and they retain the " name " of the group, clan or lineage. In the Guianas, a garden, and even a village, only remains associated with its owner/creator until it is time to abandon it and create anew (although the choice of location for a new village will often be at least partly informed by considerations of kinship and affinity). Social space cannot be taken for granted. Places are historical, and people « belong » to places only insofar as they belong to their creators through kinship. For this reason, it is impossible to say of the Guianas what Strathern says of Melanesia - that land produces people and social groups.

Anderson (1998) shows how, among Siberian hunter-gatherers, personal affinity, sensibility and skill create links to particular places, and " entitlement » becomes a part of a "sentient ecology » which " refers to set understandings in the reciprocal action between human persons and other non-human persons » (ibid., p. 75). If property relations are conventionally seen as relations « between humans » with regard to things, then Anderson suggests that for the Evenki they are less anthropocentric and recognise the agency of « other than human persons » (ibid., p. 82). This has a clear parallel in the Trio case, where property, instead of a relationship between persons with regard to things, often appears to be a relationship between persons (human and/or non-human) tout court.

Carrier focuses on how property relations are seen to change during exchange transactions in Melanesia. He argues that the distinctions between gifts and commodities imply « inclusive » and " exclusive » notions of property respectively (Carrier 1998, p. 86). By showing that, for inclusive notions of property to work, actors need to have both the desire and the power to maintain their relationship with any given item, and that this does not always occur, Carrier qualifies Strathern's argument emphasising the "plural and composite... relationships » (ibid., p. 89) that produce objects, showing that in Melanesia things are not always persons, and thus blurring the distinction between gifts and commodities; he reinforces this by suggesting an alternative focus on a distinc- 
tion, or continuum, between inclusive and exclusive property, which as we have seen has some resonance among the Trio. Meanwhile, formal rules of who has a « right » in something often give way to the effects of personal influence, blurring the practical distinction between power and justice (ibid., p. 97). Carrier thus asserts the importance of considering property not only in terms of principles, but also in terms of practices. This has clear echoes in the case presented above, where ownership and leadership, creativity and control are closely entwined.

Both Anderson and Carrier note that to understand property cross-culturally, it needs to be seen as an aspect of power relations which may be constituted in ways which are culturally specific, whether by nature or in their modes of combination. At the same time, they show that property relations are often determined by practice - the result of choices and power relations in particular situations rather than by sets of principles. This makes it more difficult to make radical typological distinctions between "Western » and "non-Western » societies, while making it easier to speak of categories such as property cross-culturally.

\section{CONCLUSION}

Property exists in Amazonia in a form which is characteristic of the region. This form is not radically opposed to Western property, as it has certain points in common such as the emphasis on transforming or domesticating the environment. This fact alone should provide reason enough to base anthropological definitions of property on ethnography, rather than on the definitions of economists or jurists. As for previous discussions of property in the region: it is clearly incorrect to claim that Amerindians have eradicated coercion and inequality by refusing the existence of property (Overing 1986). If indeed they did lack coercion and inequality ${ }^{40}$, it is not for want of property relations. On the other hand, appropriation does not necessarily resemble predation, and is rarely expressed in such terms. Property relations as practised in indigenous Guiana are founded upon personal relationships (including those with non-human persons), upon historical contingency and the narratives that these create. They constantly change, with certain exceptions, manifested in lasting material objects such as rattles, bone flutes, feathers and beads.

A clue for further study on this subject lies in Strathern (s. d.) and CorsínJiménez's (2003) attempt to see land as both a tangible and intangible resource. In Amazonia, the relationship between intellectual property and the property of land can perhaps be said to be more than just analogous: there is no distinction between the two because what ties people to places is knowledge and transformation, interaction and skill; in short, what Ingold (2000) calls « dwelling ». Numerous studies have shown the extent of the transformative action of Amazonian peoples on their physical environments (e.g. Posey and Balée 1989), and the 
acknowledgement of the anthropogenic nature of land may be the key to drawing together knowledge and territoriality, intellectual property and land rights ${ }^{41}$.

Because they emphasize relationships - especially those of creativity and transformation - rather than things themselves, social networks are of fundamental importance to Amazonian property. Strathern (1996) has suggested that property cuts and defines networks, giving them form both in the sense of social networks (networks of people) and of actor networks [which include non-human « actants » (Latour 1997)]. In this article I have shown how property relations cut and define social networks in Amazonia, especially by creating social space and articulating relationships between social actors. Beyond lowland South America, if the form of social networks is what we more usually refer to as " society », and if property relations give them this form, then they play a fundamental role in social life. *

* Manuscrit reçu en septembre 2008, accepté pour publication en décembre 2009.

\section{Notes}

1. I developed and wrote this article as boursier postdoctoral at the musée du quai Branly in Paris. It is based upon fieldwork carried out among the Trio, Wayana and Akuriyo of southern Suriname and French Guiana. I gratefully acknowledge the generosity of my hosts there, and the ESRC and musée du quai Branly for funding my research. The text has developed through various versions starting as part of my PhD thesis (Brightman 2007) and was presented in revised versions at the Séminaire d'anthropologie américaniste at the Maison des sciences de l'homme de Paris in May 2007, and at the Séminaire Branly at the musée du quai Branly in February 2008. I am grateful to all those who have offered their comments at different stages, particularly Laurent Berger, Jean-Pierre Chaumeil, Vanessa Grotti, Stephen Hugh-Jones, Carlo Severi, Anne Christine Taylor, Diego Villar and the anonymous reviewers of the Journal de la Société des Américanistes.

2. Costa (2007) and Fausto (2008b) are rare exceptions. There have been some discussions of property as land rights or traditional knowledge in Amazonia (e.g. Brown 1998, 2003; Posey and Dutfield 1996), but these do not attempt to understand indigenous forms of property.

3. This tradition, which can be said to have begun with Rousseau (1992 [1754]), finds expression in Clastres (1974) and Overing (1986).

4. As Bell $(1998$, p. 29$)$ has shown, following Macpherson, the modern European notion of "property » developed from the sense of a "characteristic » of a person indicating social position (e.g. land as an extension of a person in the case of a " man of property ") into the sense of transferable rights to things, with the advent of capitalism. Far from showing that the anthropological notion of property should be defined as "transferable» rights as Bell proposes, I would contend that this historical transformation demonstrates that Europe developed a special case out of an idea of property more widely shared among different cultures and consistent with the etymological origin of " property » as referring to attributes of personhood (from Latin proprius, " one's own, special »).

5. I limit the discussion here to verb constructions expressing possession, because such constructions are used to make explicit statements about states of possession, and they are able to distinguish between different types of possession. Parts of speech such as possessive pronouns are of less interest because they do not distinguish between different types of possession, and they are commonly used in statements which emphasise things other than possession itself. 
6. In the Xingú, effective leaders are also « masters of the village ground » (Menget 1993, p. 71; see Heckenberger 2005). Costa (2010 in this issue) shows that the Kanamari associate leadership, ownership and, in addition, the body, in one word, which he glosses as " owner-body-chief ", raising interesting questions of scale and self-similar models of relatedness.

7. Itupon, people/animals of the forest, have the same characteristics each from their own perspective. An armadillo or an agouti, for example, has its own pata. Similarly, other peoples such as the Chané and the Ayoreo appear to categorise the entire universe in terms of property; the Chané classify animals according to their owners (either iyareta masters or humans), and for the Ayoreo all creatures in the universe are owned by one of their seven clans (Diego Villar personal communication 2008).

8. See Brightman (2007) for further details on these points.

9. "Les exploitants agricoles peuvent bénéficier de concessions provisoires (5 ha maximum) qui, si les conditions de mise en valeur sont respectées, deviennent leur propriété après une période probatoire de 5 ans, renouvelable " (Geode 2000, p. 212). In Colombia, as in the Guianas, tierra baldia can become the property of anyone who clears it. In addition, if it is alienated from him, the alienator must compensate him for his improvements (Stephen Hugh-Jones personal communication 2006). This highlights still further that land or space can be occupied, but only its artificial transformations can be owned.

10. See note above, and see « squatting » or adverse possession rights (http://www.propertylawuk .net/adversepossessionsquatters.html).

11. In some other areas of Amazonia " houses of transformation " and archetypal houses have greater importance (e.g. Northwest Amazonia, Stephen Hugh-Jones personal communication 2006). But even here the relationship between people and territory is not necessarily privileged on either side. Freire (2002, p. 218) gives the intermediate case of the Piaroa, for whom «the little interest... for personal genealogies contrasts with their careful account of land genealogies ».

12. By contrast, in Melanesia knowledge of human relationships is as important as the memory of who has occupied which places (Strathern s. d.).

13. This view, which received its classic treatment in Rivière (1969), and which is supported by my own observations, has been contested recently, notably for the Trio by Grupioni (2002).

14. See Brightman (s. d.) for further discussion of this.

15. A distinction should be made between the " forest » as a category and situational relationships to locations « in » the forest, because paths and locations where a known event has taken place such as cutting down a tree, killing an animal or gathering are partially socialised by the human activity that has taken place there.

16. "Founder" is a very appropriate word to use, as another meaning of entu is the "base [or foundation] of a mountain " (Carlin 2004, p. 461). As Rivière (1995, p. 197) puts it, " the term entu can be glossed as "owner" but its semantic range is wider than that. It also has the sense of "origin" or "root", something from which a thing has sprung ". Note the similarity between the association of leadership and ownership here and the same association in feudal dominium (Testart 2003, p. 5).

17. See Lévi-Strauss's observation among the Nambikuara that «the leader appears as the cause of the group's willingness to aggregate » (Lévi-Strauss 1944, p. 22).

18. This recalls the relationships of compadrazgo of the upper Amazon, but in this case it is far less formalized and does not carry obligations.

19. A tenth of the size - Tëpu includes about 300 people, and pre-missionary populations were roughly 30 (Rivière 1984).

20. ... although a secondary name with a topographical derivation was sometimes also used.

21. The larger "village " corresponds more closely to the cluster of autonomous settlements, loosely linked by kinship relations, that Rivière (1984) calls an « agglomeration ".

22. Similarly, on the Paru de Leste, the villages of Apalai and Maxipurimo were founded by rubber tappers and by the German traveller Manfred Rauschert respectively (Barbosa 2002, p. 124).

23. See Grotti (2007) for discussion of extended personhood among the Trio and Wayana.

24. Chapuis comments that feathers for the Wayana are lexically and conceptually « not differentiated » from hair [umhe (IV), ime (T)]. Hair is regarded as " the seat of a power which also 
links them to the person; so, when cut, it must be treated correctly or risk harming its wearer; one can make the hypothesis that the same is true of the bird feathers/hairs which, maintaining some of the power of their previous owners, bring them to their new wearer; they create a new identity " (Chapuis 1998 , p. 374; my translation). In addition to their beauty, then, it is the vital power of the feathers that makes them valuable.

25. I was unable to obtain consistent general information on heirlooms, but the importance of feathers and other ritual items recalls other areas, such as Northwest Amazonia, where headdresses are among the highly valued objects passed on from father to son (Stephen Hugh-Jones personal communication). According to Darbois (1956, p. 51), Wayana beads and feather headdresses were buried, along with weapons, with the dead. But Damien Davy (personal communication 2007) informs me that Wayana feather headdresses are indeed inherited patrilineally. One of my anonymous readers offers to resolve this contradiction by suggesting that Darbois and Davy may be referring to two separate types of headdress: the pumali would be buried and the hamele and olok inherited.

26. In Paramaribo, a maluwana was sold for $3 €$ per $\mathrm{cm}$ diameter in 2005 . A small maluwana $43 \mathrm{~cm}$ in diameter could therefore be sold for $129 €$, a considerable sum of money in Tëpu.

27. See Viveiros de Castro (1996).

28. The Declaration on the Rights of Indigenous Peoples was adopted by the UN general assembly on 13th September 2007 (IWGIA 2007). See Kuper (2003) for a controversial critique of the movement that has led to this declaration, and Brightman (s. d.) for further discussion.

29. Here it is worth noting that certain onomastic systems recycle a fixed number of names to which they give great significance, as a form of property, whereas others do not (I am grateful to Diego Villar for suggesting this; see also Taylor 1993). However, I do not think that it is easy to distinguish clearly between the two types in Amazonia. Societies such as the Trio do not have an explicitly fixed set of names, but names are not duplicated, and there is a tendency to acquire names from foreign peoples.

30. See Hugh-Jones (2002) for a comparison of these themes in both regions.

31. Chiefly names and chiefly discourse are the " property » of primary chiefs (Heckenberger 2005, p. 246), and Heckenberger refers to these names as "symbolic property" and "inalienable possessions » (ibid., p. 272). History itself is regarded as the " exclusive property » of the most senior chiefs, whose privilege it is to tell the stories of the eight great chiefs (ibid., p. 286). While these are features of Arawakan societies exhibiting a level of formal hierarchical organisation that is not shared by other, relatively egalitarian, societies of Amazonia (Diego Villar personal communication 2008), I suggest that the difference is one of degree rather than kind.

32. Descola (2001) argues that there is a general rule in Amazonia of "homosubstitution ", whereby persons are not substituted or exchanged for things. However, as Descola (e.g. 2005) himself would be the first to acknowledge, the difference between persons and things cannot be taken for granted. Moreover, as Hugh-Jones (s. d.) has shown, it is problematic to take for granted that Amazonian societies are never " bridewealth » societies; there are exceptions to the rule.

33. The Trio and Wayana also distinguish between animals and inanimate objects such as money; for instance, meat usually cannot be bought and sold. Yet this does not seem to be merely a matter of whether an animal is a " person ", for dogs, which are certainly " persons ", have long been routinely traded for trade objects or money.

34. In fact, villages have recently become more permanent and certain individuals have been accumulating objects (see above and Brightman 2007; Freire 2002).

35 . Western philosophy and ideologies are continually projected on ethnographic subjects; for examples, compare Overing (1986) with Rousseau (1992), and Chagnon (1974) with Hobbes (1996).

36. Property being arguably the principal thing that primitive proto-societies were supposed to lack (see Locke 1988). A notable attempt to address this problem has been made by Thomas (1982), who, without resorting to idealism, has directly addressed the question of how Guianese peoples can achieve " order without government ».

37. Ironically, Amazonian Indians were quick to recognise forms of property that they could relate to among European colonizers, and the presence of property institutions in Amazonian societies 
explains why they adopted these European forms with such speed in addition to their own (Diego Villar personal communication 2008).

38. See Viveiros de Castro (1998) for the classic exposition of Amerindian perspectivism.

39. It therefore seems equally odd to neutralise these as « space ".

40. See Brightman (2007), in which I argue that they do not.

41. The cognitive aspects of plant knowledge may also help to shed further light on indigenous Amerindian notions of property, and further investigation of the classification of and interaction with the spirit world and the living environment should therefore also be given a central role in future research on the subject - see Lenaerts (2006) and Brightman (2008b).

\section{REFERENCES CITED}

\section{ANDERSON David}

1998 "Property as a way of knowing on Evenki lands in Arctic Siberia », in Chris Hann (ed.), Property relations: renewing the anthropological tradition, Cambridge University Press, Cambridge, pp. 64-84.

\section{BARBosa Gabriel}

2002 Formas de intercâmbio, circulação de bens e a (re)produção das redes de relações apalai e wayana, masters dissertation, University of São Paolo, São Paolo.

\section{BeLl Duran}

1998 "The social relations of property and efficiency ", in Robert Hunt and Antonio Gilman (eds), Property in economic context, University Press of America, New York, pp. 27-44.

Brightman Marc

2007 Amerindian leadership in Guianese Amazonia, PhD dissertation, University of Cambridge, Cambridge.

2008a "Ownership and trade of persons and plants in Guianese Amazonia ", paper presented at the Society for the Anthropology of Lowland South America sesquiennial meeting, Oxford, 17th-21st June.

2008b "Ethnopharmacology, money and social relations among the Trio and Wayana of southern Suriname », in Marc Lenaerts and Ana-María Spadafora (eds), Pueblos indigenas, plantas y mercado - Amazonia y Gran Chaco, Zeta, Bucharest.

s. d. $\quad$ "Strategic ethnicity on the global stage: perspectives on the indigenous peoples movement from the central Guianas to the United Nations ", Boletin de la sociedad suiza de americanistas [in press].

BRown Michael

1998 "Can culture be copyrighted? », Current anthropology, 39 (2), pp. 193-222.

2003 Who owns native culture? Harvard University Press, Cambridge Mass.

Carlin Eithne

2004 A grammar of Trio. A Cariban language of Suriname, Peter Lang, Frankfurt. 
CARrIER James

1998 "Property and social relations in Melanesian anthropology », in Chris Hann (ed.), Property relations: renewing the anthropological tradition, Cambridge University Press, Cambridge, pp. 85-103.

Chagnon Napoleon

1974 Studying the Yanomamö, Holt, Rinehart and Winston, New York.

Chapuis Jean

1998 La personne wayana entre sang et ciel, thesis, Université Aix-Marseille, Aix-en-Provence.

Clastres Pierre

1974 La société contre l'État, Les Éditions de Minuit, Paris.

CoRsín-JiMÉnez Alberto

2003 "On space as a capacity », Journal of the Royal Anthropological Institute, (ns) 9, pp. 137-153.

Costa Luiz

2007 As faces do jaguar: Parentesco, história e mitologia entre os Kanamari da Amazônia Ocidental, thesis, Museu Nacional, Rio de Janeiro.

2010 "The Kanamari Body-Owner. Predation and feeding in Western Amazonia ", Journal de la Société des Américanistes, 96 (1), pp. 169-192.

DarboIs Dominique

1956 Yanamale, village of the Amazon, Collins, London.

Descola Philippe

1986 La nature domestique: symbolisme et praxis dans l'écologie des Achuar, Éditions de la Maison des Sciences de l'Homme, Paris.

2001 "The genres of gender: local models and global paradigms in the comparison of Amazonia and Melanesia ", in Thomas Gregor and Donald F. Tuzin (eds), Gender in Amazonia and Melamesia: an exploration of the comparative method, University of California Press, Berkeley, pp. 91-114

2005 Par-delà nature et culture, Gallimard, Paris.

Fausto Carlos

2008a «Possessive dividualism: observations on mastership and ownership in Amazonia ", paper presented at Humains, amimaux, plantes et choses: la notion de personne en Amazonie et Sibérie contemporaines, musée du quai Branly, Paris, 22nd-23rd June.

2008b "Donos demais: maestria e domínio na Amazônia », Mana, 14 (2), pp. 329-366.

Fock Niels

1963 Waiwai: religion and society of an Amazonian tribe, The National Museum, Copenhagen.

FREIRE German

2002 The Piaroa: environment and society in transition, $\mathrm{PhD}$ dissertation, University of Oxford, Oxford. 


\section{Geode Caraïbe}

2000 La question de la terre dans les colonies et départements français d'Amérique 1848-1998, Karthala, Paris.

Goldman Irving

1963 The Cubeo: Indians of the Northwest Amazon, University of Illinois Press, Urbana.

\section{GrEgor Thomas}

1977 Mehinaku: the drama of daily life in a Brazilian Indian village, University of Chicago Press, Chicago.

\section{Grotri Vanessa}

$2007 \quad$ Nurturing the other: wellbeing, social body and transformability in Northeastern Amazonia, PhD dissertation, University of Cambridge, Cambridge.

\section{Grupioni Denise Fajardo}

2002 Sistema e mundo da vida Tarëno: um " jardim de veredas que se bifurcam » na paisagem Guianesa, thesis, Universidade de São Paolo, São Paolo.

\section{Hann Chris (ed.)}

1998 Property relations: renewing the anthropological tradition, Cambridge University Press, Cambridge.

\section{HECKENBERGER Michael}

2005 The ecology of power: culture, place and personhood in the Southern Amazon, A.D. 1000-2000, Routledge, Abingdon.

Hirsch Eric and Marilyn Strathern (eds)

2004 Transactions and creations: property debates and the stimulus of Melanesia, Berg, Oxford.

\section{HoBBes Thomas}

1996 Leviathan, Cambridge University Press, Cambridge [1651].

HowaRd Catherine

2001 Wrought identities: the Waiwai expeditions in search of the "unseen tribes ", $\mathrm{PhD}$ dissertation, University of Chicago, Chicago.

\section{Hugh-JoNes Stephen}

1979 The palm and the Pleiades: initiation and cosmology in Northwest Amazonia, Cambridge University Press, Cambridge.

2002 "Nomes secretos e riqueza visível: nominação no noroeste amazônico ", Mana, 8 (2), pp. 45-68.

2009 "The fabricated body: objects and ancestors in Northwest Amazonia ", in Fernando Santos Granero (ed.), The occult life of things: Native Amazononian theories of materiality and personhood, University of Arizona Press, Tucson.

s. d. "Brideservice and the absent gift ». 
Hume David

1975 "Of justice », in Lewis Amhurst Selby-Bigge (ed.), Enquiries concerning human understanding and concerning the principles of morals, Clarendon Press, Oxford, pp. 183-204 [1777].

INGOLD Tim

2000 The perception of the environment: essays in livelihood, dwelling and skill, Routledge, London.

IWGIA

2007 http://www.iwgia.org/sw248.asp, accessed 14th December.

Kambel Ellen-Rose and Fergus MacKaY

1999 The rights of indigenous peoples and maroons in Suriname, IWGIA, document $\mathrm{n}^{\circ} 96$, Copenhagen.

KaLinoe Lawrence and James LeACH (eds)

2004 Rationales of ownership: transactions and claims to ownership in contemporary Papua New Guinea, Sean Kingston, Wantage.

KARADIMAS Dimitri

2000 " Parenté en esclavage. Pratiques matrimoniales et alliances politiques chez les Miraña d'Amazonie colombienne», Droit et cultures, 39, pp. 81-100.

KUPER Adam

2003 "The return of the native », Current anthropology, 44 (3), pp. 389-402.

LATOUR Bruno

1997 Nous n'avons jamais été modernes: essai d'anthropologie symétrique, La Découverte, Paris.

LEA Vanessa

1995 «The houses of the Mebengokre (Kayapó) of Central Brazil - a new door to their social organization ", in Janet Carsten and Stephen Hugh-Jones (eds), About the house: Lévi-Strauss and beyond, Cambridge University Press, Cambridge, pp. 206-225.

Lévi-Strauss Claude

1944 "The social and psychological aspects of chieftainship in a primitive tribe: the Nambikuara of Northwestern Mato Grosso ", Transactions of the New York Academy of Science, 7, pp. 16-32.

1962 La pensée sauvage, Plon, Paris.

LENAERTS Marc

2006 "Ontologie animique, ethnosciences et universalisme cognitif: le regard ashéninka ", L'Homme, 179, pp. 113-140.

LOCKE John

1988 Two treatises of government, Cambridge University Press, Cambridge [1690].

MAYBURY-LewIS David

1974 Akwe-Shavante Society, Oxford University Press, Oxford. 


\section{MCCALlum Cecilia}

2001 Gender and sociality in Amazonia: how real people are made, Berg, Oxford.

Menget Patrick

1993 «Les frontières de la chefferie », L'Homme, 126-128, pp. 59-76.

Merleau-Ponty Maurice

1945 Phénomenologie de la perception, Gallimard, Paris.

Moutu Andrew

$2004 \quad$ Names are thicker than blood: concepts of ownership and person amongst the Iatmul, PhD dissertation, Cambridge University, Cambridge.

NeALE Walter

1998 "Property : law, cotton-pickin' hands, and implicit cultural imperialism », in Robert Hunt and Antonio Gilman (eds), Property in economic context, University Press of America, New York, pp. 47-64.

OVERING Joanna

1975 The Piaroa, a people of the Orinoco basin: a study in kinship and marriage, Clarendon, Oxford.

1986 "Men control women? The catch 22 in the analysis of gender », International journal of moral and social studies, 1 (2), pp. 135-156.

Overing Joanna and Alan PASSES

2000 "Introduction », in Joanna Overing and Alan Passes (eds), The anthropology of love and anger: the aesthetics of conviviality in native Amazonia, Routledge, London.

Posey Darrell A.

2004 Indigenous knowledge and ethics: a Darrell Posey reader, Routledge, New York.

Posey Darrell and William BaLÉE (eds)

1989 Resource management in Amazonia: indigenous and folk strategies, New York Botanical Garden, New York.

Posey Darrell and Graham DuTFIELD

1996 Beyond intellectual property, International Development Resource Center, Ottawa.

RIVIÈRE Peter

1969 Marriage among the Trio, Clarendon, Oxford.

1984 Individual and society in Guiana, Cambridge University Press, Cambridge.

1993 "The amerindianisation of descent and affinity ", L'Homme, 126-128, pp. 507-516.

1995 "Community and continuity in Guiana ", in Janet Carsten and Stephen Hugh-Jones (eds), About the house: Lévi-Strauss and beyond, Cambridge University Press, Cambridge, pp. 189-205.

Rousseau Jean-Jacques

1992 Discours sur l'origine et les fondements de l'inégalité parmi les hommes, Flammarion, Paris [1754]. 
Ryan Alan

1986 Property and political theory, Blackwell, Oxford.

SANTOS Granero Fernando

2009 Vital enemies: slavery, predation and the Amerindian political economy of life, University of Texas Press, Austin.

\section{Sмith Adam}

1978 " The origin and development of our property rights ", in Ronald Meek, David Raphael and Peter Stein (eds), Lectures on jurisprudence, Clarendon Press, Oxford [ca 1762].

STRATHERn Marilyn

1996 "Cutting the Network », Journal of the Royal Anthropological Institute, (ns) 2, pp. 517-535.

1999 Property, substance and effect, Athlone, London.

s. d. "The tangible and the intangible: a holistic analysis? », in André Iteanu (ed.), Memorial volume for Daniel de Coppet.

TAYLOR Anne Christine

1993 «Remembering to forget: identity, mourning and memory among the Jivaro ", Man, (ns) 28, pp. 653-678.

Testart Alain

2003 «Propriété et non-propriété de la terre. L'illusion de la propriété collective archaïque (1 $1^{\text {re }}$ partie) "), Études rurales, 165-166, pp. 209-242 [ http://etudesrurales.revues.org/document 146.html].

ThOMas David

1982 Order without government: the society of the Pemon Indians of Venezuela, University of Illinois Press, Urbana.

TURNER Terence

1979 "The Gê and Bororo societies as dialectical systems ", in David MayburyLewis (ed.), Dialectical societies: the Gê and Bororo of Central Brazil, Harvard University Press, Cambridge Mass.

Verdery Katherine and Caroline Humphrey (eds)

2004 Property in question: value transformation in the global economy, Berg, Oxford.

VienNe Emmanuel de and Olivier Allard

2005 "Pour une poignée de dollars? Transmission et patrimonialisation de la culture chez les Trumai du Brésil central ", Cahiers des Amériques latines, 48-49, pp. 127-145.

Viveiros de Castro Eduardo

1996 "Images of nature and society in Amazonian ethnology », Annual Review of Anthropology, 25, pp. 179-200.

1998 "Cosmological deixis and Amerindian perspectivism ", Journal of the Royal Anthropological Institute, 4 (3), pp. 469-488. 
WidLOK Thomas and Wolde Gossa TADEsSE (eds)

2006

Property and equality. Vol. I. Ritualization, sharing, egalitarianism; vol. II. Encapsulation, commercialization, discrimination, Berghahn, Oxford.

WoODBuRn James

1998 «Sharing is not a form of exchange: an analysis of property-sharing in immediate-return hunter-gatherer societies ", in Chris Hann (ed.), Property relations: renewing the anthropological tradition, Cambridge University Press, Cambridge, pp. 48-63. 